\title{
Media Composition and Light Affect Storability and Poststorage Recovery of Micropropagated Hosta Plantlets
}

\author{
Sandra B. Wilson ${ }^{1}$ and Nihal C. Rajapakse \\ Department of Horticulture, Clemson University, Clemson, SC 29634-0375

\begin{abstract}
Roy E. Young ${ }^{2}$ Clemson, SC 29634-0357
\end{abstract} \\ Department of Agricultural and Biological Engineering, Clemson University,
}

Additional index words. Hosta tokudama, postharvest physiology, in vitro, low temperature storage, photoautotrophic, photomixotrophic, spectral quality

\begin{abstract}
Hosta (Hosta tokudama Makeawa 'Newberry Gold') plantlets were micropropagated photoautotrophically (without sucrose in medium) or photomixotrophically (with $2 \%$ sucrose in medium) for 3 weeks at $23{ }^{\circ} \mathrm{C}$ under $80 \mu \mathrm{mol} \cdot \mathrm{m}^{-2} \cdot \mathrm{s}^{-1}$ photosynthetic photon flux $(P P F)$ prior to long-term storage. Plantlets were stored for 4,8 , or 12 weeks at 5,10 , or $22{ }^{\circ} \mathrm{C}$ in darkness or under white $(400-800 \mathrm{~nm})$, blue $(400-500 \mathrm{~nm})$, or red $(600$ $700 \mathrm{~nm}$ ) light at or near light compensation points. Illumination during storage was necessary to maintain dry weight and regrowth potentials of plantlets in vitro, but light quality had no effect on these parameters. All photoautotrophic plantlets stored in darkness were of poor quality at the time of removal from storage and died when transferred to the greenhouse. Dark-stored photomixotrophic plantlets survived storage for 12 weeks at $5^{\circ} \mathrm{C}$, but declined in appearance (visual quality) as the storage duration increased. Decline in visual quality was greater when plantlets were stored at 10 and $22{ }^{\circ} \mathrm{C}$. Leaf dry weight of illuminated plantlets increased and percentage of leaf yellowing decreased as storage temperature increased. Recovery of illuminated plantlets from photomixotrophic storage was best when plantlets were stored at $22{ }^{\circ} \mathrm{C}$. These plantlets were characterized by increased visual quality (color and form) and increased dry weight compared with those in other treatments. After 60 days in the greenhouse, the dry weight of these plantlets was similar for 4-, 8-, and 12-week storage durations, indicating flexibility in storage time if specific light and temperature provisions are met.
\end{abstract}

The increased use of perennials has contributed to a renewed interest in the Hosta genus; in fact, hosta may well be the perennial plant of the decade (Jones and Jones, 1990). The popularity of hosta is attributed to its decorative foliage, attractive inflorescence, and ability to fill shady areas in the landscape. Hosta plants are propagated by division of lateral shoots. However, because only a few shoots can be obtained from some taxa, introduction of a new cultivar can take several years. Tissue culture offers poten-

Received for publication 23 Dec. 1999. Accepted for publication 11 Jan. 2000. Technical contribution No. 4580 of the South Carolina Agricultural Experiment Station. We thank William Bridges of the Dept. of Experimental Statistics at Clemson Univ. for his help in statistical analysis of the data. This research was supported by a grant from the U.S. Dept. of Agriculture, National Research Initiative Competitive Grants Program (Project No. 9500909). The cost of publishing this paper was defrayed in part by the payment of page charges. Under postal regulations, this paper therefore must be hereby marked advertisement solely to indicate this fact.

${ }^{1}$ To whom reprint requests should be addressed Current address: 2199 South Rock Road, Indian River Research and Education Center, University of Florida, Fort Pierce, FL 34945. E-mail address: Sbwilson@gnv.ifas.ufl.edu

${ }^{2}$ Current address: Department of Agricultural and Biological Engineering, Pennsylvania State University, University Park, PA 16802. tial for rapid clonal multiplication (Paek and Ma, 1996). The rapid availability of many new and exciting hosta cultivars is in part due to the use of tissue culture as a means of commercial propagation. However, advantages of tissue culture, such as rapid production, greater uniformity, and disease elimination, are often counteracted by high production costs and low profits. The ever-changing consumer demand for certain hosta taxa is sometimes difficult to predict and labor costs for the seasonal production of hosta are equally difficult to distribute. Storage of micropropagated plantlets for extended times in large numbers per unit area would be useful to the horticultural industry. In addition to ensuring availability of seasonal ornamental crops and distributing labor costs, techniques of holding micropropagated plantlets could significantly affect the globalization of markets where preserving plantlet quality during extended shipping periods is crucial.

Storage systems that minimize growth without sacrificing quality require the manipulation of light, temperature, and medium composition. Storage of plants at their light compensation point (where photosynthesis balances respiration) has proven effective in minimizing excessive elongation. Kubota et al. (1995) have shown that low temperature, in conjunction with fluorescent lighting at photosynthetic photon flux $(P P F)$ as low as $2 \mu \mathrm{mol} \cdot \mathrm{m}^{-2} \cdot \mathrm{s}^{-1}$, maintained photosynthetic ability and dry weight of photoautotrophic broccoli(Brassica oleracea L., Botrytis group) seedlings stored for 6 weeks. In the photoautotrophic system, the micropropagated plant is dependent on its own production of photosynthates rather than on an exogenous carbon source in the form of sugar. Kubota and Kozai (1995) showed that light compensation points of stored plants vary with air temperature and sugar level in the medium. Addition of sucrose to the medium increased dry weight, soluble sugars, and visual quality of plantlets (Wilson et al., 1998a, 1998b). However, omitting from or reducing the level of sucrose in the medium can facilitate growth by promoting of autotrophy, decreasing expense of materials, and reducing biological contamination (Kozai, 1991).

Light quality is another important factor affecting plant growth and development (Economou and Read, 1987; Sergeeva et al., 1994). Most studies on the effects of spectral composition on plant growth have been performed on whole plants. Sprinchanu and Butenko (1991) observed that red light increased internode length and root formation during in vitro culture of Artemisia balchanoorum H. Kraschen. Bertazza et al. (1995) found that red light enhanced in vitro root development of pear (Pyrus communis L.) cultivars. In our previous work, red light improved the storage of broccoli seedlings in vitro (Wilson et al., 1998a).

Low temperature storage has been used widely for preserving postharvest quality of horticultural commodities. Provision of light during low temperature storage can improve the quality of plantlets during storage. Recently, researchers found that red light irradiation during cool temperature storage of strawberry (Fragaria $\times$ ananassa Duchesne) plants increased leaf area, chlorophyll content, and photosynthetic rates (Nishizawa et al., 1997). However, few reports exist on low temperature storage of in vitro plantlets. Broccoli seedlings can survive illuminated storage in vitro at $5{ }^{\circ} \mathrm{C}$ for up to 6 weeks (Kubota et al., 1996), but not more than 8 weeks (Wilson et al., 1998a). Storage at $1{ }^{\circ} \mathrm{C}$ improved plantlet quality and regrowth potential, with red light being particularly effective in increasing dry weight and photosynthetic capacity of stored seedlings (Wilson et al., 1999). However, various plant species respond differently to low temperatures (Lange et al., 1991). Therefore, for each new species stored in vitro, various temperatures must be explored to pinpoint optimum conditions for high quality plants. In the current research, we investigated the influence of light (provided by fluorescent tubes or light emitting diodes during storage at intensities near the light compensation point) and temperature $\left(5,10\right.$, and $\left.22^{\circ} \mathrm{C}\right)$ on storability and poststorage recovery of micropropagated hosta plantlets.

\section{Materials and Methods}

Plant material and culture conditions. In vitro 'Newberry Gold' hosta plantlets (Carter and Holmes, Newberry, S.C.) were subcultured 
photoautotrophically (no sugar in the medium) or photomixotrophically (2\% sucrose in the medium) for 3 weeks in Murashige and Skoog (1962) liquid media (10 mL per plantlet) supplemented with vitamins (Gamborg, 1970). Four plantlets were cultured on Sorbarod cellulose support plugs (Sorbarod, Baumgartner Papiers SA, Switzerland) in $375 \mathrm{~mL} \mathrm{GA-7}$ vessels (Magenta, Chicago). Two 10-mm-diameter holes in opposite sides of the vessel were covered with $0.5 \mu \mathrm{m}$ membrane filter disks (Milli-Seal, Millipore K.K., Tokyo) to provide $\approx 3.2$ air exchanges per hour (Kozai et al., 1986). Culture room temperature was $23 \pm$ $2{ }^{\circ} \mathrm{C}$ during the 16 -h photoperiod and $19 \pm 1{ }^{\circ} \mathrm{C}$ during the 8 -h dark period. $P P F$ was $80 \pm 20$ $\mu \mathrm{mol} \cdot \mathrm{m}^{-2} \cdot \mathrm{s}^{-1}$ on the culture shelf.

Determination of light compensation point. Three weeks after culture initiation, in vitro plantlets were transferred to smaller GA-7-3 vessels (Magenta) without membrane filters. The vessels were capped with Magenta lids, and the closure was sealed with sculpting clay and Parafilm ${ }^{\circledR}$ to prevent gas from escaping. Vessels were stored at 1,10 , and $15{ }^{\circ} \mathrm{C}$ in separate low-temperature incubators (Precision 815; Precision Scientific, Chicago) equipped with overhead lighting from $15-\mathrm{W}$ cool-white fluorescent tubes (General Electric F15T12-CW), red light emitting diodes (Stanley Co., Irvine, Calif.), or $20-\mathrm{W}$ blue fluorescent tubes (General Electric F20T12B) at $1.6,4.1$, or $8.6 \mu \mathrm{mol} \cdot \mathrm{m}^{-2} \cdot \mathrm{s}^{-1} P P F$. Light intensities within the incubator were adjusted by application of mesh screening. Light intensity was measured on the culture shelf in an empty vessel covered with a lid. Spectral distributions of the three light sources in storage have been reported previously (Wilson et al., 1998a). A 0.5-mL gas sample was taken from the head space of each vessel at 12-h intervals during storage, and $\mathrm{CO}_{2}$ concentration inside the vessels was measured using a gas chromatograph with a thermal conductivity detector (model 8A; Shimadzu Co., Kyoto, Japan). Gas sampling was terminated after $3 \mathrm{~d}$ when $\mathrm{CO}_{2}$ concentration inside the vessels reached a steady state.

Storage treatments. In three consecutive but independent experiments, vessels containing in vitro seedlings were stored for 4,8 , or 12 weeks at 5,10 , or $22^{\circ} \mathrm{C}$. At $5^{\circ} \mathrm{C}$, plantlets were stored in darkness or under $7 \mu \mathrm{mol} \cdot \mathrm{m}^{-2} \cdot \mathrm{s}^{-1}$ of white or blue light or $4.5 \mu \mathrm{mol} \cdot \mathrm{m}^{-2} \cdot \mathrm{s}^{-1}$ of red light (average light compensation points from previous experiment). At $10^{\circ} \mathrm{C}$, plantlets were stored in darkness or under $8 \mu \mathrm{mol} \cdot \mathrm{m}^{-2} \cdot \mathrm{s}^{-1}$ of white light, $7.5 \mu \mathrm{mol} \cdot \mathrm{m}^{-2} \cdot \mathrm{s}^{-1}$ of blue light, or $6.5 \mu \mathrm{mol} \cdot \mathrm{m}^{-2} \cdot \mathrm{s}^{-1}$ of red light (average light compensation points from previous experiment). At $22^{\circ} \mathrm{C}$, plantlets were stored in darkness or under $11 \mu \mathrm{mol} \cdot \mathrm{m}^{-2} \cdot \mathrm{s}^{-1}$ of white light (an estimated light compensation point based on previous experiments). Blue and red light quality treatments were not administered. At the start of storage, the air diffusive filters of the vessel were covered with plastic tape to minimize the number of air exchanges and to avoid excessive water loss.

Post storage recovery in the greenhouse. Upon removal from storage at 4,8 , or 12 weeks, plantlets from two vessels were transferred to soilless media (Metro Mix 360; The Scotts Co., Marysville, Ohio) in 804 grow packs and placed under mist in the greenhouse for 4 weeks. Plantlets were removed from mist and grown in a different greenhouse location without mist for an additional 4 weeks. Visual quality of plantlets (based on color and form) was assessed biweekly by three people and an average rating was recorded. Visual quality evaluations were based on a scale from 1 to 5 , whereby 1 = very poor quality, severe leaf necrosis, leaf yellowing, not marketable; 2 = poor quality, large areas of leaf necrosis, leaf yellowing, not marketable; 3 = fair quality, marginally marketable; 4 = good quality, no yellowing, marketable; and $5=$ excellent quality, no leaf necrosis, no yellowing, highly marketable. After 8 weeks in the greenhouse, leaf dry weights were determined and plant survival rates recorded.

Experimental design, data collection, and statistical analysis. Experiments were conducted similarly but independently (due to a limited number of low temperature incubators) at 5,10 , and $22{ }^{\circ} \mathrm{C}$. Vessels (photoautotrophic and photomixotrophic) were randomized under each light treatment. Five photoautotrophic and five photomixotrophic vessels were harvested from each light treatment after $0,4,8$, or 12 weeks of storage. Each vessel with four plantlets was considered a replication. Three vessels from each treatment were used for dry weight measurements, and two were used for poststorage recovery analysis in the greenhouse. Data were analyzed by analysis of variance (ANOVA) and treatment differences were separated by LSD at $P=0.05$.

\section{Results and Discussion}

Light compensation points. Light compensation points increased as storage temperature increased from 1 to $15^{\circ} \mathrm{C}$. Therefore, the light intensity was increased by $\approx 1.5 \mu \mathrm{mol} \cdot \mathrm{m}^{-2} \cdot \mathrm{s}^{-1}$ $P P F$ for every $5{ }^{\circ} \mathrm{C}$ increase in storage temperature to reach the light compensation point. Storage at (or near) the light compensation point is particularly desirable for maintaining plants in a relatively "slow growth" status without excessive shoot elongation and dry weight increase (Kubota et al., 1995).

Regardless of storage temperature, light compensation points were higher when sucrose was provided in the medium (data not shown). Plantlets grown under red light had the lowest light compensation points, regardless of medium composition or storage temperature. Because both photoautotrophic and photomixotrophic plantlets were stored in the same incubator, average light compensation points were used for long-term storage experiments.

Dry weight and leaf yellowing. Regardless of medium composition, light quality did not affect plant growth during or after storage at 5 and $10^{\circ} \mathrm{C}$. This supports previous research by Kubota et al. (1996), who showed that micropropagated hosta plantlets stored at $5{ }^{\circ} \mathrm{C}$ for 6 weeks did not respond to red or blue fluorescent lights. Therefore, blue and red data are not presented for the 5 and $10{ }^{\circ} \mathrm{C}$ experiments, and white light was used as the only light source during the $22{ }^{\circ} \mathrm{C}$ storage experiment. Plant species apparently differ in response to light quality during low temperature storage, since in previous experiments red light promoted growth of broccoli seedlings (Wilson et al., 1998a).

Regardless of temperature or medium composition, illumination in storage helped maintain dry weight of plantlets better than did dark storage. During dark storage, dry weight of photomixotrophic plantlets was better maintained than that of photoautotrophic plantlets. At $5{ }^{\circ} \mathrm{C}$, photoautotrophic plantlets stored in darkness were considered dead after 4 weeks (Fig. 1A), whereas the leaf dry weight of photomixotrophic plantlets stored in darkness gradually decreased by $\approx 50 \%$ during the first 4 weeks and then remained relatively unchanged (Fig. 1B). At $10^{\circ} \mathrm{C}$, leaf dry weight of photoautotrophic plantlets stored in darkness had fallen more than $50 \%$ after 4 weeks and the plantlets were considered dead after 8 weeks (Fig. 1C), whereas the leaf weight of photomixotrophic plantlets decreased by $\approx 60 \%$ during the first 8 weeks of storage and then slightly increased. At $22^{\circ} \mathrm{C}$, the leaf dry weight of photomixotrophic plantlets stored in darkness gradually decreased to almost zero after 8 weeks (Fig. 1F). Dark storage of photoautotrophic plantlets was not tested at $22{ }^{\circ} \mathrm{C}$ because of poor survival at lower temperatures.

Illumination helped maintain the dry weight of plantlets during storage. When photoautotrophic plantlets were stored under white light, dry weight slightly increased during storage at $22{ }^{\circ} \mathrm{C}$, slightly decreased during storage at $10{ }^{\circ} \mathrm{C}$, and dramatically decreased during storage at $5{ }^{\circ} \mathrm{C}$. When photomixotrophic plantlets were stored under white light, dry weight decreased during storage at 5 and $10{ }^{\circ} \mathrm{C}$, and increased during storage at $22^{\circ} \mathrm{C}$. Stability of dry weight during storage indicates that light compensation points were reached.

Illumination in storage reduced leaf yellowing of photoautotrophic plantlets (Fig. $2 \mathrm{~A}$ and C). At $5^{\circ} \mathrm{C}, 92 \%$ of leaves were yellow or dead after 4 weeks of dark storage, whereas at $10^{\circ} \mathrm{C}$, excessive leaf yellowing was not observed until after 8 weeks. Leaf yellowing of photomixotrophic plantlets after 12 weeks storage was $\approx 63 \%$ at $5{ }^{\circ} \mathrm{C}$ and $\approx 45 \%$ at $10{ }^{\circ} \mathrm{C}$, regardless of whether plantlets were stored in darkness or under illumination (Fig. 2 B and D). However, when photomixotrophic plantlets were stored at $22^{\circ} \mathrm{C}$, leaf yellowing of dark-stored plantlets was $\approx 18$ times greater than that of plantlets stored under illumination (Fig. 2F).

Visual quality and final dry weight in the greenhouse. Regardless of storage temperature, visual quality of plantlets at the time of removal from storage decreased as in vitro storage time increased from 4 to 12 weeks (data not shown). Therefore, only visual quality data from plantlets stored for 12 weeks (longest treatment) at 5,10 , and $22^{\circ} \mathrm{C}$ is shown (Fig. 3). All dark-stored photoautotrophic plantlets failed to recover in the greenhouse and were considered dead (Fig. $3 \mathrm{~A}$ and C). 
Photoautotrophic plantlets had good visual quality when stored under illumination 10 and $22^{\circ} \mathrm{C}$ (Fig. $3 \mathrm{C}$ and $\mathrm{E}$ ), but poor visual quality when stored at $5^{\circ} \mathrm{C}$ (Fig. $3 \mathrm{~A}$ ).

Photoautotrophic plantlets stored in light or darkness had lower visual quality ratings (reduced dry weight and increased leaf yellowing) in the greenhouse than did photomixotrophic plantlets (Fig. $3 \mathrm{~A}-\mathrm{F}$ ), confirming previous research (Wilson et al. 1998a). All photomixotrophic plantlets stored at $5{ }^{\circ} \mathrm{C}$ survived acclimatization to the greenhouse, and there were no visual quality differences between dark- and light-stored plantlets. At $10^{\circ} \mathrm{C}$, dark-stored plantlets had lower visual quality ratings than did light-stored plantlets (Fig. 3 B and D), but plantlets were still considered marketable. However, at $22{ }^{\circ} \mathrm{C}$, darkstored plantlets were etiolated and never recovered after storage (Fig. 3 F). This indicates that the optimum temperature for dark storage of photomixotrophic hosta plantlets is $5{ }^{\circ} \mathrm{C}$. For photomixotrophic plantlets stored under illumination, the initial visual quality (immediately prior to transfer to the greenhouse) was best when plantlets were stored at $22^{\circ} \mathrm{C}$ rather than at 5 or $10{ }^{\circ} \mathrm{C}$. However, regardless of storage temperature, visual quality increased with time in the greenhouse. Initially (immediately after removal from storage), better quality hosta plantlets were obtained by increasing the storage temperature, thereby preventing the perennial plants from entering dormancy. This differs from previous research, where lowering storage temperature from 5 to $1{ }^{\circ} \mathrm{C}$ improved storability of broccoli seedlings in vitro; better survival rates at $1{ }^{\circ} \mathrm{C}$ were attributed to reduced metabolism and high carbohydrate reserves (Wilson et al., 1999).

Although photomixotrophic plantlets recovered from illuminated storage after 4 weeks in the greenhouse (increased visual quality rating), final dry weights (measured after 8 weeks in the greenhouse) were still comparably lower for plantlets stored at 5 or $10^{\circ} \mathrm{C}$, presumably because of reduced carbohydrate partitioning to crown tissue (Wilson et al., 1998b). Final dry weight of plantlets decreased as storage time increased to 12 weeks for all treatments with the exception of photomixotrophic plantlets stored under white light at $22{ }^{\circ} \mathrm{C}$, whose final dry weights remained constant regardless of storage time (Fig. 4 AF). This suggests that at $22{ }^{\circ} \mathrm{C}$, photomixotrophic hosta plantlets can be stored for up to 12 weeks at their light compensation point $\left(\approx 11 \mu \mathrm{mol} \cdot \mathrm{m}^{-2} \cdot \mathrm{s}^{-1}\right)$ and grown in the greenhouse for 8 weeks without change in dry matter or visual quality. Avoiding refrigerated storage reduces production cost and facilitates transportation of plantlets; however at $22^{\circ} \mathrm{C}$, illumination must be provided for even a short storage duration.

Final dry weight was greatest after 8 weeks in the greenhouse, when photoautotrophic and photomixotrophic plantlets were stored under illumination, with the exception of photomixotrophic plantlets stored at 5 or $10^{\circ} \mathrm{C}$, in which light did not affect dry weight. This suggests that plantlets can be stored in darkness at 5 or $10{ }^{\circ} \mathrm{C}$ with visual quality and dry weight comparable with those of plantlets stored under low illumination $\left(\approx 7-8 \mu \mathrm{mol} \cdot \mathrm{m}^{-2} \cdot \mathrm{s}^{-1} P P F\right)$. This information may be particularly useful during conditions of long-distance shipping of plantlets when illumination is not possible and space is limited.

In conclusion, illumination is required for storage of photoautotrophic hosta plantlets between $5-22{ }^{\circ} \mathrm{C}$, and recommended for storage of photomixotrophic plantlets at higher temperatures $\left(10-22^{\circ} \mathrm{C}\right)$. Sucrose must be supplied in the medium to maintain high quality plantlets during storage. Optimal temperatures for illuminated storage of photomixotrophic hosta plantlets are $10-22{ }^{\circ} \mathrm{C}$. Decreasing the storage temperature from $22^{\circ} \mathrm{C}$ to 10 or $5^{\circ} \mathrm{C}$ decreases the dry weight and visual quality of the plantlets when initially transferred to the greenhouse, although plantlets recover after 4 weeks (increased visual quality) and are considered marketable. The survivability and strong regrowth potential of stored hosta plantlets indicated that carbohydrates were partitioned and stored in the crown tissue. These reserves were probably depleted in plants stored in darkness and were limiting in plants stored without sucrose. The effects of low temperature storage on the carbohydrate status and photosynthetic ability of hosta are currently under investigation.
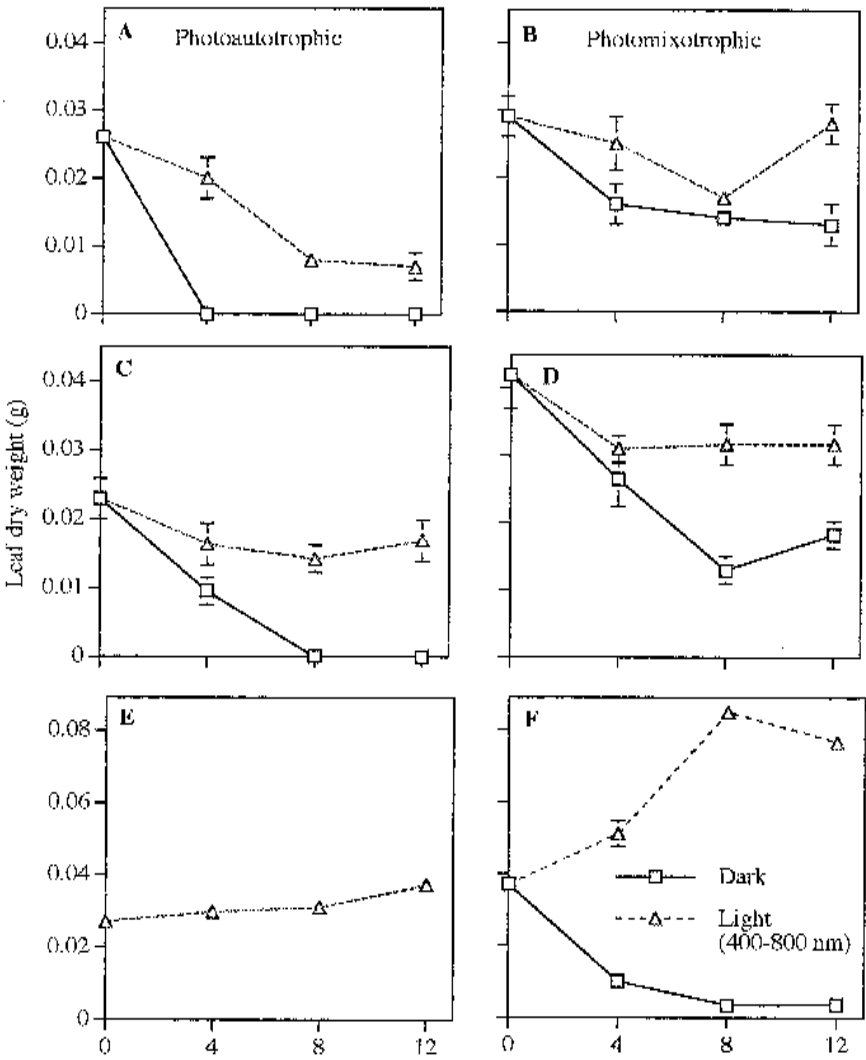

Storage time (wocks)

Fig. 1. Mean $( \pm \mathrm{SE})$ leaf dry weights as a function of storage time in weeks of photoautotrophic and photomixotrophic hosta plantlets incubated either in the dark $(\square)$ or under light $(\Delta)$ at: $(\mathbf{A}, \mathbf{B}) 5^{\circ} \mathrm{C} ;(\mathbf{C}, \mathbf{D}) 10^{\circ} \mathrm{C}$; or $(\mathbf{E}, \mathbf{F}) 22^{\circ} \mathrm{C}$.
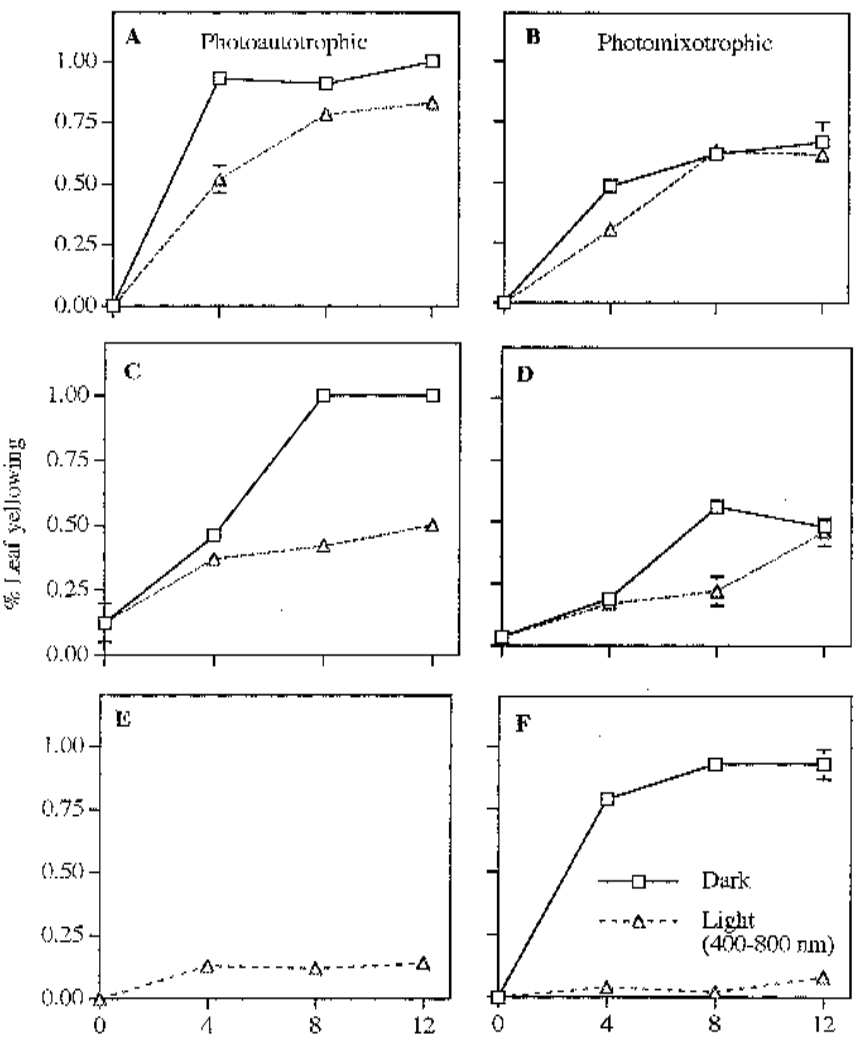

Storige time (weeks)

Fig. 2. Mean $( \pm$ SE $)$ percentage of leaf yellowing as a function of storage time in weeks of photoautotrophic and photomixotrophic hosta plantlets incubated either in the dark $(\square)$ or under light $(\Delta)$ at: $(\mathbf{A}, \mathbf{B}) 5^{\circ} \mathrm{C} ;(\mathbf{C}, \mathbf{D}) 10^{\circ} \mathrm{C}$; or $(\mathbf{E}, \mathbf{F}) 22^{\circ} \mathrm{C}$. 


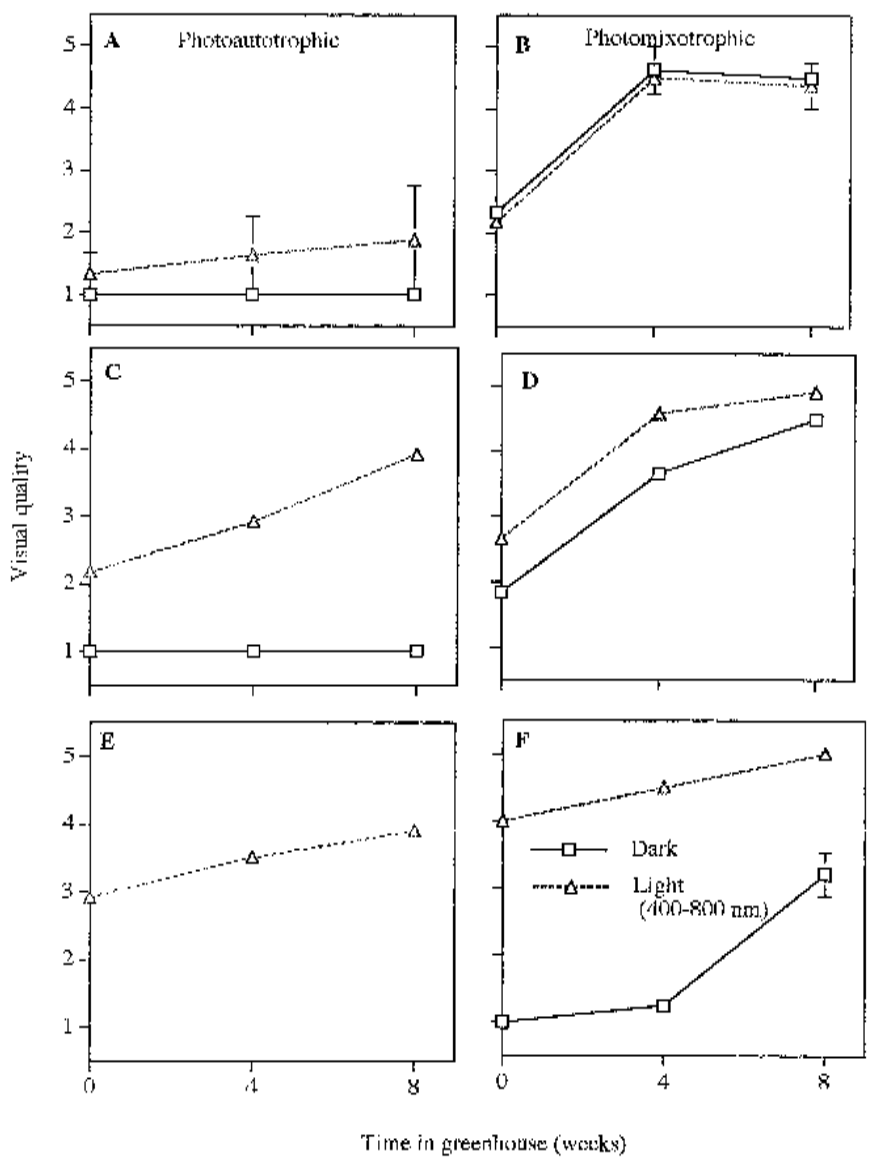

Fig. 3. Mean ( $\pm \mathrm{SE})$ visual quality (color and form) of hosta plantlets during 8 weeks of growth in the greenhouse after photoautotrophic or photomixotrophic storage for 12 weeks at: $(\mathbf{A}, \mathbf{B}) 5^{\circ} \mathrm{C} ;(\mathbf{C}, \mathbf{D}) 10^{\circ} \mathrm{C}$; or $(\mathbf{E}, \mathbf{F}) 22{ }^{\circ} \mathrm{C}$, either in the dark $(\square)$ or under light $(\Delta)$. Visual quality evaluations were based on a scale from 1 to 5 , whereby $1=$ very poor quality, severe leaf necrosis, leaf yellowing, not marketable; $2=$ poor quality, large areas of leaf necrosis, leaf yellowing, not marketable; $3=$ fair quality, marginally marketable; 4 = good quality, no yellowing, marketable; and 5 = excellent quality, no leaf necrosis, no yellowing, highly marketable.
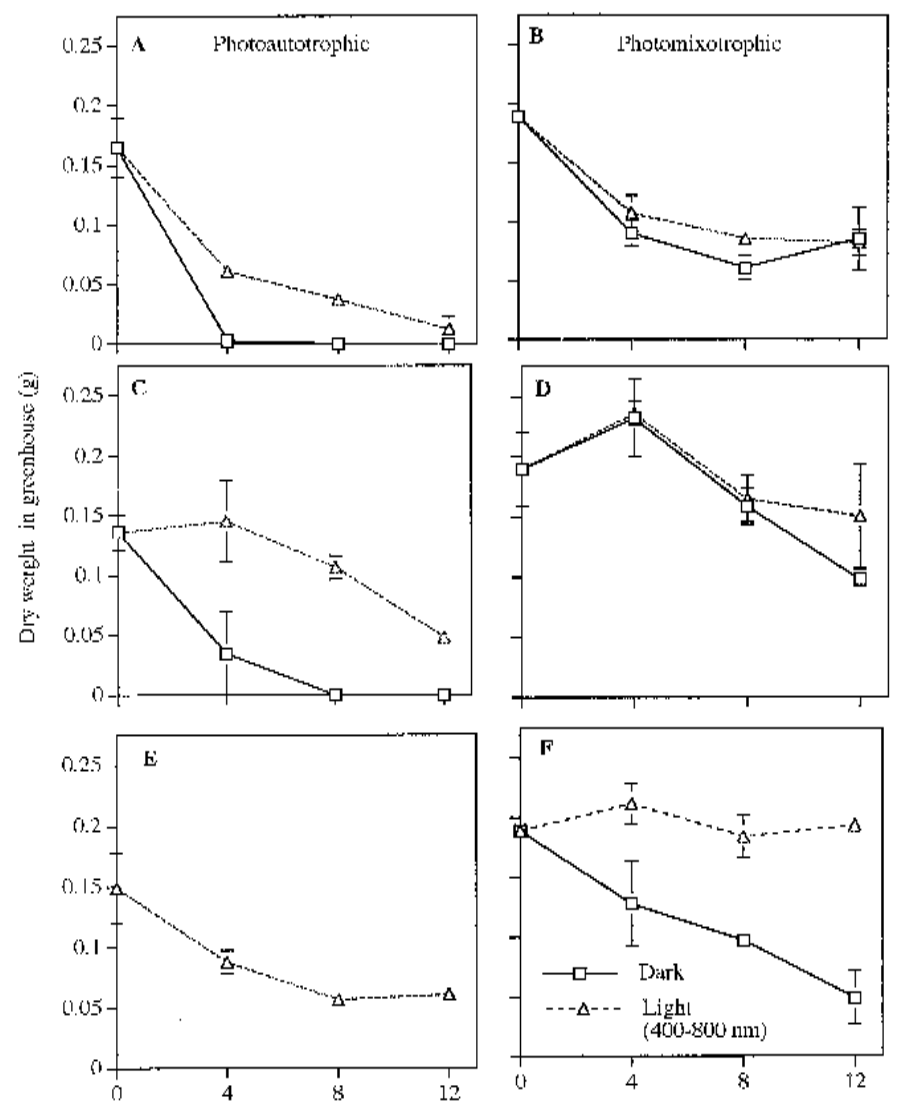

Storage time (wock)

Fig. 4. Mean ( \pm SE) dry weight of hosta plantlets grown for $60 \mathrm{~d}$ in the greenhouse following photoautotrophic or photomixotrophic storage for $0,4,8$, or 12 weeks at: $(\mathbf{A}, \mathbf{B}) 5^{\circ} \mathrm{C} ;(\mathbf{C}, \mathbf{D}) 10^{\circ} \mathrm{C}$; or $(\mathbf{E}, \mathbf{F}) 22^{\circ} \mathrm{C}$, either in the dark $(\square)$ or under light $(\Delta)$.

\section{Literature Cited}

Bertazza, G., R. Baraldi, and S. Predieri. 1995. Light effects on in vitro rooting of pear cultivars of different rhizogenic ability. Plant Cell Tiss. Org. Cult. 41:139-143.

Economou, A.S. and P.E. Read. 1987. Light treatments to improve efficiency of in vitro propagation systems. HortScience 22:751-753.

Gamborg, O. 1970. The effects of amino acids and ammonium on the growth of plant cells in suspension culture. Plant Physiol. 45:372-375.

Jones, S.B. and C. Jones. 1990. In hosta heaven. Amer. Nurseryman 172:47-50.

Kozai, T. 1991. Micropropagation under photoautotrophic conditions, p. 447-469. In: P.C. Debergh and R.H. Zimmerman (eds.). Micropropagation. Kluwer Academic Publishers, Dordrecht, The Netherlands.

Kozai, T., K. Fujiwara, and I. Watanabe. 1986. Fundamental studies on environments in plant tissue culture vessels. (2) Effects of stoppers and vessels on gas exchange rates between inside and outside of vessels closed with stoppers. J. Agr. Meteorol. 42:119-127.

Kubota, C. and T. Kozai. 1995. Low-temperature storage of transplants at the light compensation point: Air temperature and light intensity for growth suppression and quality preservation. Scientia Hort. 61:193-204.

Kubota, C., G. Niu, and T. Kozai. 1995. Low temperature storage for production management of in vitro plants: Effects of air temperature and light intensity on preservation of seedling dry weight and quality during storage. Acta Hort. 393:103-110.

Kubota, C., N.C. Rajapakse, and R.E. Young. 1996. Low-temperature storage of micropropagated seedlings under selected light environments. HortScience 31:449-452.

Lange, N., R. Heins, and W. Carlson. 1991. Store plugs at low temperatures, p. 22-28. In: Greenhouse Grower Jan.

Murashige, T. and F. Skoog. 1962. A revised medium for rapid growth and bioassays with tobacco tissue cultures. Physiol. Plant. 15:473497.

Nishizawa, T., Y. Shishido, M. Kudo, H. Kumakura, and H. Hamamoto. 1997. Petiole length, chlorophyll and carbohydrate levels, and photosynthetic rates of June-bearing strawberry plants as influenced by red-light irradiation during storage under cool conditions. Scientia Hort. 72:25-33.

Paek, K.Y. and S.H. Ma. 1996. In vitro propagation of hosta using cultured shoot tips and somaclonal variability of regenerants. Acta Hort. 440: 576-581.

Sergeeva, L.I., I. Machackova, T.N. Konstantinova, S.A. Golyanovskaya, J. Eder, O.O. Zaltsman, J. Hanus, and N.P. Aksenova. 1994. Morphogenesis of potato plants in vitro. II. Endogenous levels, distribution, and metabolism of IAA and cytokinins. J. Plant Growth Regulat. 13:147-152.

Sprinchanu, E.K. and R.G. Butenko. 1991. Effect of light spectral composition of growth and development of Artemisia balchanorum cuttings in vitro. Fiziologiya Rastenii 38:561-568.

Wilson, S.B., K. Iwabuchi, N.C. Rajapakse, and R.E. Young. 1998a. Responses of broccoli seedlings to light quality during low temperature storage in vitro. I. Morphology and survival. HortScience 33:1253-1257.

Wilson, S.B., K. Iwabuchi, N.C. Rajapakse, and R.E. Young. 1998b. Responses of broccoli seedlings to light quality during low temperature storage in vitro. II. Sugar content and photosynthetic efficiency. HortScience 33:1258-1261.

Wilson, S.B., N.C. Rajapakse, and R.E. Young. 1999. Use of low temperature to improve storage of in vitro broccoli seedlings under various light qualities. J. Veg. Crop Prod. (In Press). 